\title{
The Art of Involving Students in Sciences' Learning Using Educational Software Programs
}

\author{
Ne us a N F*, Elize te Lucia M M \\ School of Education and Humanities, Pontifical Catholic University of Parana, Curitiba, Parana, Brazil
}

\begin{abstract}
Currently, teachers are confronted with several technological tools which can help them on daily teaching activities, and besides the vast majority of software can be considered educational. But what are the criteria for particular software to be considered educational? How can the use of software involve students in their learning? In this article, we present a survey of known educational software, aiming to analyze its applicability in the educational process in science education, specifically in Chemistry. The software was developed by teachers who use themes from everyday life and can be applied to high school students. Along with the research results, we will emphasize the concern in the careful choice of software, pointing it as a great pedagogical ally in the art of involving the learner in the process of teaching and learning.
\end{abstract}

Keywords Research, Educational Software, Pedagogical Applicab ility

\section{Introduction}

Due to the rapid knowledge dissemination which currently, we educators face ourselves involved daily, practice invites us to experience an educational scenario increasingly directed to research and to the use of innovative tools and, consequently, more motivating which provide greater and better benefits to express in an original and efficacious way the art of teaching. It is against this new reality that it is the teacher who has to relentless research for pedagogically relevant resources in order to engage and provoke the students' curiosity aligned to the needs of a more interesting, entertaining and independent knowledge production. In this scenario and with all the computing resources available, we find some educational software which may be used as a support to teaching, enriching the pedagogical practice and providing motivation moments of great interest to students. It has been observed that the virtual media are playing an increasingly important role as an educational proposal, enabling reproductions of real-world phenomena and allowing students to print into their work realism and superior quality in their learning, something difficult to achieve in the conservative forms of education.

Aware of these new possibilities, and knowing that students learn best when they are provided an adequate vocabulary, a familiar environment to their daily life and specially the freedom to discover the existing relationship between what is learned and the reality that is lived, we

* Corresponding author:

neusa_nf@y ahoo.com.br (Neusa N F)

Published online at http://journal.sapub.org/edu

Copyright (C) 2012 Scientific \& Academic Publishing. All Rights Reserved propose with this paper a contribution to the action teacher/ student, especially in the area of Chemistry in an investigative and analytical research of three known educational software: Carbópolis, the Game of Things and Buying Organic Compounds in the Supermarket. The applications mentioned above are of the type simulators / games and aim to give students opportunities to develop and test hypotheses, to analyze results, to intervene and get involved, reaching their own conclusions in a playful and independent way, mixing simulations and games in an unique enrichment of the teaching / learning process.

\section{Students' Involvement}

For a while teachers have been learning how to cope with the lack of motivation, interest, attention, concentration and even understanding which eventually prevent the content applied to be suitable. It is known, however, that not everything that is taught, interests everyone nor in the same way, which makes learning to be selected and prioritized by the recipient, thus creating a natural mechanism for selection of learn ing.

Changing this scenario is a strategic task for the teacher. In accordance to exp lanations by Moran, the teacherneeds to be concerned to "learn to balance organizational processes and 'provocation' in the classroom", try ing to involve students in the process of teaching and learning. Therefore, he/she can and should make use of information and communication technologies (ICTs) in order to turn the act of learning into something motivating, interesting, engaging and fun[12].

Students are increasingly infected by a variety of technological resources and thus become part of a new group called "digital generation"[14]. Changes in this "new" 
student profile who was born in this fully computerized era and that carries with it a whole media cultural background, favors and even drives the teacher to keep up in order to guarantee a bilateral learning.

In this sense, there is a teacher-researcher who upon facing new technologies tends to adapt them and use them accordingly in favor of a learning which is richer and engaging, innovative and close to the reality of students. Freire states that "there is no teaching without research or research without teaching"[8, p. 29]. Researching, seeking and understanding should also be awakened in the learner and this will only happen if the teacher creates mechanisms which involve the students, encouraging them to travel these paths together.

Juca argues that new technologies do not release the teacher as a person, instead, they require fro $\mathrm{m}$ him/her to add to the profile new and more complex requirements such as: how to deal with their students individual rhythms, to take ownership of new techniques to prepare teaching materials produced by electronic means, to work in virtual environments different from the traditional teaching of the university, to acquire a new language and to learn how to creatively manage the technology offered[11].

Thus, it is very important that teachers and students are involved in the same project, are curious, feel motivated by research as instigator beings, because "it is necessary, even essential, that the teacher be rested in knowing that the cornerstone is the curiosity of human beings" [8, p. 86].

It is appropriate, then, that the teacher is attentive and provides moments of experience, knowledge exchanges, and significant quests, and, especially he needs to be available to listen, to talk and to show that he is open to understand the real interests of the students, promoting meaningful and dynamic classes.

The use of technology in education significantly increases the chances of developing a richer and more interesting pedagogical work for the student. However, the planning of educational situations is indispensable, and for that purpose it may be guided on the pillars of Delors proposal for an Education for the twenty-first century which allows students to: "learn to learn", "learn to do", "learn to be" and "learn to live with"[6].

As well as those from other disciplines, the chemical contents can be presented and explored through various educational resources mediated by technologies, such as educational software, forums, blogs, chats and so on.

In Moran's view the acquisition of information will depend less and less on the teacher. Technology can bring today's data, images, summaries in a quickly and attractive way. The teacher's role - the main role - is to help the student to interpret, to relate and to contextualize these data. The educator's role is to mobilize the desire to learn, so that the student feels always hungry to know more[12].

The teacher's role, therefore, in possession of these new technologies is to engage, motivate, delight and captivate students for the process of teaching / learning to occur naturally and significantly, which is just the art of involving to teach.

\section{Use of Software for Student Involvement}

The technologies of communication and information are present in our daily life with increasing innovations, facilitating knowledge through new representations and have been gradually inserted in the educational field. One of the tools offered by ICTs is the computer and its use in schools allowing an expansion of teaching strategies that can promote the building of knowledge in teaching and learning.

Through associated technologies it is possible to enhance the educational process, especially regarding the Internet, because it offers a variety of resources among which our focus here is restricted to the use of educational software to support science education, with emphas is on chemistry.

Based on these assumptions, the following question arises: when can software be considered educational? Despite being a topic of discussion, by the disagreement on what turns out to be an educational software, we agree with some authors regarding their conceptualizations. Costa and Oliveira, for example, claim that "educational software (ES) is one type of program developed especially for teaching, with the main objective of enabling students to develop the learning of certain content" [5].

Freire and Prado point out that "[...] when it comes to a software for educational purposes, the theoretical and pedagogical foundation demand special attention. It is necessary to observe the specifications of the software on the intended audience, its method of use, support materials needed related to the use of software, presentation of content (consistency and structure) and to stimulate creativity, imagination, reasoning, teamwork and the user's level of involvement"' 9 ].

According to Campos, the development of educational software seeks to contemplate the characteristics of education leading to the overall training of the student who needs learning to learn and to think in order to act, innovate and challenge better[3]. Chaves states that the educational software should be conceptualized in terms of its function, not of its nature[4]. Thus, through educational software it is possible to represent knowledge in different ways and with diffe rent types of software, which Vie ira classified according to the educational objectives, the following categories: tutorials, programming, applications, exercises and practices, multimedia and the Internet as well as modeling and simu lation games[16].

However, we highlight the following types of educational software: games (The Game of Things) and simulations (Carbópolis and Buying Organic Compounds in the Supermarket) chosen for analysis and explanation in this paper.

\subsection{Games}

These are programs in which the student has the freedom 
to learn by playing. For Aranha, "electronic games have been seen as ess ential tools for the educational training and mental health"[1]. In this type of program, the student controls the stages of the game respecting its rules and becomes able to develop skills like: concentration, memory and organization needed for certain concepts.

We agree with Moran when he says that the game teaches you to live with rules and to find solutions to challenges, in part, foreseen. In play ing there is more freedom of creation, reorganization, and both are important for learning. We learn through games to live with rules and limits, exploring new possibilities. We learn by playing, the variables and innovations based on our goals or people[12].

\subsection{Simulations}

This kind of software provides the students a virtual display of real situations in which you can handle issues involving time, acceleration, distance, risks and so on. So, according to Honey e Hilton "simulations and games have great potential to improve science learning in elementary, secondary, and undergraduate science class-rooms. They can individualize learning to match the pace, interests, and capabilities of each particular student and contextualize learning in engaging virtual environments"[10].

The simulation may be closed, that is, similar to the tutorials or open, as in scheduling. In closed simu lations, the student does not find many challenges and so, according to Valente, the phenomenon is first implemented on the computer, and the values of some parameters are likely to be altered by the learner[15].

In fact, every software offers an explicit way to contribute to the educational process, some prioritizing only memory which in many cases is necessary, others favoring challenges, tests, data analysis, hypotheses survey, not requiring much intervention by the teacher.

As a result, we must reflect that to convert the software tools for educational innovation in teaching practices which address the interaction between teacher and student, teacher participation becomes essential, both in the careful choice of software to be used as in their education and mediation therefore of no use as many teaching resources if the teacher is not able to develop them with the students.

We talk about fitness by the teacher, in the sense that he has the instructional knowledge of how is the performance of the chosen software to work with the students, as well as the domain to play the role of mediator in the activity in order to instruct and at the same time involve them in its use.

Therefore, it is important to note that the use of educational software should be done with great responsibility, coherence and common sense in order to achieve educational purposes, allowing the student to develop skills so significant that he becomes an individual active in the process of building his knowledge.

There are no ready models for teaching, nor such powerful tools to vehemently solve many difficulties found in the professional practice. On the other hand, there are such diverse and constructive resources which can assist you in the educational process in order to contribute to a collaborative and transformative learning. There fore, the use of educational software in teaching practices should be seen as a support to teaching, that is, another tool, able to motivate and energize classes leading to the participation and interaction between teacher and student, so that both learn and build together.

\section{Software Description}

Current ICTs present appealing and engaging data, images and movements which can open pedagogical paths to the teacher. Barros explains that the integration of technologies provides new forms to facilitate the performance of both teachers and students, allowing the realization of various types of work, the use of various types of resources and pathways, facilitating the customization learning process[2]. Based on these assumptions, we discuss the following description of the software analyzed in this paper.

\subsection{Carbópolis}

Carbópolis is an educational software that was developed by the Division of Chemical Education of the Institute of Chemistry, UFRGS (Federal University of Rio Grande do Sul), in partnership with the Special Training Program of the Informatics Institute of UFRGS.

The main objective of Carbópolis is to provide space for the students to discuss one of the issues related to environmental pollution and, therefore, the authors created a scenario where a city appears on the screen (Carbópolis) with various situations which lead the learner to list the problems that appear as an interview. The problems are listed in a notebook which will subsequently allow the student to make his own report indicating solutions to the problems encountered. The simulation was the mean used to achieve this goal.

All in Carbópolis, despite having a strong relationship with reality, is just a representation of it and its characters and statements are fictitious. Thus, to achieve the purpose proposed it is adapted to support all texts relating to environmental pollution which embody such software.

The authors want you as a student, to propose solutions to the problems to be simulated, which will be presented early in the program, even recommending the use of Carbópolis to be accompanied by someone who already knows or has used it, pre ferably, a teacher.

In seeking solutions, the student works with hypotheses and proposes an alternative that may be, among others, to install an anti-pollutant equipment available in the search for environmental pollution control. Carbópolis texts have to use a hypertext format. Thus, all relevant information for understanding and solving the problem in question are interconnected, making it easy for the participant to request further information. 
Thus, Eicher and Pino, creators of the software, said that it is the curiosity and the need of the student which will determine the path used for reading, as well as knowledge of the proposed problem and its solution[7].

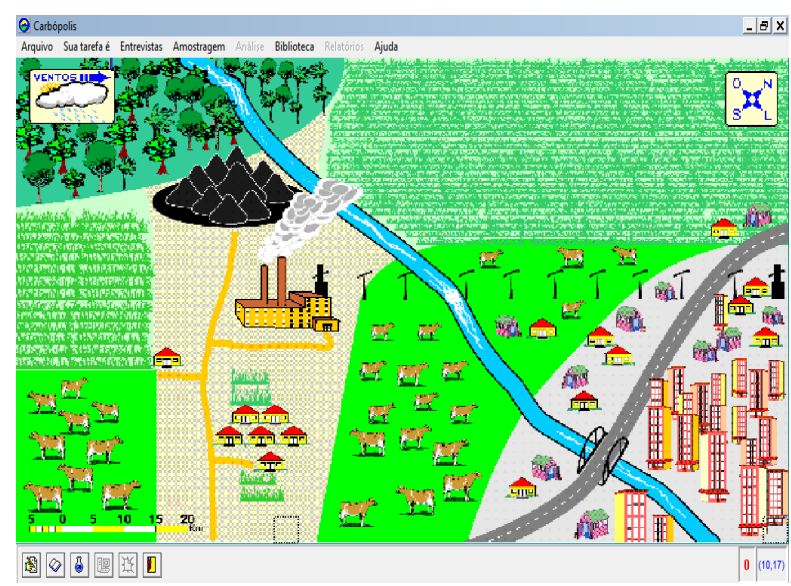

Figure 1. Presentation screen of "Carbópolis"

\subsection{Jogo das Coisas (The Game of Things)}

John Paiva and Victor M. S. Gil are the authors of this game, which has as programmer and graphic designer: Ilíd io Martins. This is a game that makes you think and can be used both in school and high school. It is available in six languages: German, English, Spanish, French, Italian and Portuguese. It covers the following subject areas: biology, geology, history, mathematics, chemistry and others. It discusses various topics within the chemistry area, such as: chemical celebrities, chemical compounds, recycling, salts and so on.

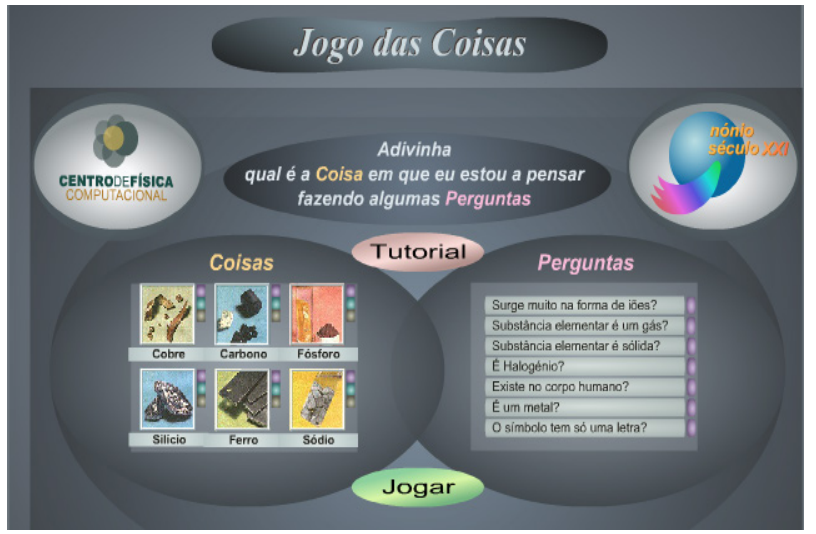

Figure 2. Presentation screen of "The game of things"

The goal is to associate an image to each question to be guessed by the student. So, the learner should know very well the contents, as for each association there is an equivalent to a positive or negative score. At the beginning of each question it will appear Y (yes) or N (No) for hits and misses. It is a great challenge!

\subsection{Buying Organic Compounds in the Supermarket}

Developed by Arigony Jose Souto, this game aims to relate the product with organic compounds found in a supermarket.
In this closed simulation software, a shopping cart keeps passing through the computer screen continuously. This simulation presents two options:

a) The first option shows an organic function and the student must click on a product off the shelf that has a compound related to the function. The name of the organic function appears randomly on the computer screen, specified on a display that is in the upper right corner of the screen, where you can view the measured time, the function name and the score; the function name appears also written at the bottom of the cart. For example, if the display shows the alcohol function, the student can click on a bottle of wine.

b) In the second option there are names of organic compounds and the student has to click on a product that has the compound. The information is displayed in the same way as in the first option. In this case, if in the display appears the compound acetic acid, the student is to choose the option vinegar, since it is the product that contains this organic compound.

Each option: organ functions or name of the predominant compounds comprehends four phases which appear in different shelves and with diversified products. The correction is made in the act of choosing, for each hit is recorded ten points, and for each error five points are deducted. Moreover, the game is timed. It is a game that can be used in series of high school.

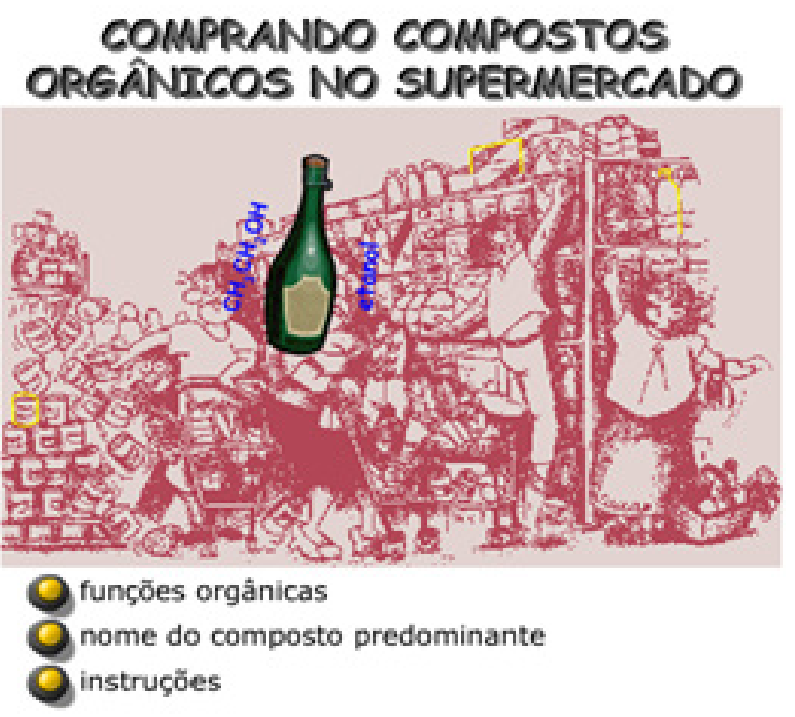

Figure 3. Presentation screen of "Buying Organic Compounds at the Supermarket"

\section{Software Comparison}

The evaluation of educational software is essential and it is up to the teacher to consider whether its application is feasible in the classroom, taking into main account its pedagogical scope.

Barros makes clear that the focus is learning, the promotion and strengthening of interactions between student and teacher and student and student, collaboration and knowledge sharing among all actors; strategies for 
collaborative work, using materials and strategies which encourage students to process information independently and significantly[2].

However, it is worth noting that in any educational software, the feedback given to the 'error' of the student is a key point in the analysis of educational software. If it does not give immediate and subjective feedback, we can classify it as 'behavioral', where there is only stimulus and response and this response does not allow the continuation of the process [16].

Therefore, the following comparative tables of the chosen software, whose included contents are directed to the Chemical Area, taking into account, among the various existing criteria, those presented in a relevant form and which emphasize the teaching and learning process.

\subsection{Comparative Table}

Our intention at this point is to clarify that educational software is still new in the field of education, but of great value to the process of knowledge production. Some bring a very interactive interface and significant contributions to science and others still need to be improved.

Table 1. Strengths and Negat ives of the Soft ware: Carbópolis

\begin{tabular}{|c|c|c|}
\hline Strengths & Negatives & Suggestions \\
\hline - Good virtual setting. & & \\
- Specific and well & & \\
directed content & & - Submit to the \\
- Exciting, clear and & - The participant & participant a \\
objective interactivity. & has no way of & feedback on the \\
- Self-explanatory and & knowing if & report sent to at \\
accessible language. & resolution is & end of the game in \\
- The participant feels & correct. & order to make it \\
inserted into the context & & clear. \\
and motivated to solve the & & \\
problems presented & & \\
\hline
\end{tabular}

Table 2. Strengths and Negatives of the Soft ware: The game of things

\begin{tabular}{|c|c|c|}
\hline Strengths & Negatives & Suggestions \\
\hline $\begin{array}{l}\text {-Excellent virtual } \\
\text { setting. } \\
\text { - Varied content. } \\
\text { - Covers wide age } \\
\text { range, } \\
\text { including the interested } \\
\text { adult audience. } \\
\text { - Sharpen the curiosity } \\
\text { of the participant. } \\
\text { - The participant } \\
\text { realizes that the } \\
\text { computer is his great } \\
\text { adversary promoting a } \\
\text { healthy } \\
\text { competitiveness. }\end{array}$ & $\begin{array}{l}\text { - The scope and } \\
\text { variety of content } \\
\text { can take the focus of } \\
\text { the student, resulting } \\
\text { in the dispersal of } \\
\text { major concern. } \\
\text { - Complicated rules } \\
\text { that can cause lack } \\
\text { of motivation on the } \\
\text { student. } \\
\text { - A little interactive. } \\
\text { - The participant is } \\
\text { guided by trial and } \\
\text { error. }\end{array}$ & $\begin{array}{l}\text { - Making the } \\
\text { rules more } \\
\text { clear and } \\
\text { accessible as } \\
\text { well as } \\
\text { avoiding } \\
\text { dispersion of } \\
\text { participants } \\
\text { offering more } \\
\text { specific } \\
\text { content to the } \\
\text { teaching of } \\
\text { chemistry. }\end{array}$ \\
\hline
\end{tabular}

Table 3. Strengths and negatives of the Software: Buying Organic Compounds at the Supermarket

\begin{tabular}{|c|c|c|}
\hline Strengths & Negatives & Suggestions \\
\hline $\begin{array}{l}\text {-Excellent virtual } \\
\text { setting. } \\
\text { - Varied content. } \\
\text {-Covers wide age } \\
\text { range, including the } \\
\text { interested adult } \\
\text { audience. } \\
\text { - Sharpen the curiosity } \\
\text { of the participant. } \\
\text { - The participant } \\
\text { realizes that the } \\
\text { computer is his great } \\
\text { adversary promoting a } \\
\text { healthy } \\
\text { competitiveness. }\end{array}$ & $\begin{array}{l}\text {-The scope and } \\
\text { variety of content } \\
\text { can take the focus of } \\
\text { the student, resulting } \\
\text { in the dispersal of } \\
\text { major concern. } \\
\text { - Complicated rules } \\
\text { that can cause lack } \\
\text { of mot ivation on the } \\
\text { student. } \\
\text { - A little interactive. } \\
\text { - The participant is } \\
\text { guided by trial and } \\
\text { error. }\end{array}$ & $\begin{array}{l}\text { - Making the rules } \\
\text { more clear and } \\
\text { accessible as well } \\
\text { as avoiding } \\
\text { dispersion of } \\
\text { participants } \\
\text { offering more } \\
\text { specific content to } \\
\text { the teaching of } \\
\text { chemistry. }\end{array}$ \\
\hline
\end{tabular}

Being aware that the art of involving to teach is a fundamental point in the commitment of teachers towards their learners and being in possession of new educational tools which can help us so much for a bilateral and sustained growth is that we feel motivated to propose a reflective analys is, through a comparative chart which will shed light to the ideas here researched, analyzed and tested.

Therefore, following, we compare the analyzed software describing their positive and negative aspects, based on research and analysis by the authors in order to strongly contribute to new methodological basis and the involvement of teachers in their art of teaching.

\section{Conclusions}

With so many changes taking place in society, both in technology and in related sciences, the school as an organization as a whole can no longer set a limit to the transmission of information only. The teaching profession needs to understand the process of teaching and learning as a way to represent knowledge, and fro $m$ there, resize already known concepts seeking to add to their teaching new models, new ideas, always worry ing about es sential values for life in a society.

Our goal for this work has focused on higher teacher education, in their contribution to the art of teaching itself, emphasizing the use of new teaching tools, which may be med iated by the use of computers and the Internet.

Therefore, although we already have a large number of educational software targeted to the areas of science, teachers find it convenient to take these alternatives, evaluating three educational softwares, identifying positive and negative aspects, in order to encourage them to explore other teaching methodologies aiming application of a more innovative, consistent and involving practice with contemporary conceptions. 


\section{REFERENCES}

[1] ARANHA, G. Jogos Eletrônicos como um conceito chave para o desenvolvimento de ap licaçõ es imersivas e interativas para o aprendizado. Ciências \& Cognição; Ano 03, v. 07, 2006. Disponível em: www.cienciasecognicao.org.

[2] BARROS, Melaré Vieira[et al]. Educação e Tecnologias: reflexão, inovação e práticas. Lisboa: 2012.

[3] CAMPOS, G. H. B. Formação e treinamento on line. O que determina a qualidade de um software educacional? 2001. Disponível em: http://www.timaster.com.br/revista/colunista s/ler_colunas_emp.asp?cod $=310$.

[4] CHAVES, E. O que é Software Educacional. 2004. Disponível em: http://www.chaves.com.br/TEXTSELF/EDT $\mathrm{ECH} /$ softedu.htm.

[5] COSTA, J. W. D; OliveIRA. M. A. M. (Org.) Novas linguagens e novas tecnologias: educação e sociabilidade. Petrópolis: Vozes, 2004.

[6] DELORS, J. The four pilars of education. UNESCO Task Force on Education for the Twenty-First Century. 1998. Disponível em: http://www.unesco.org/delors/.

[7] EICHER, M.; PINO, J. C. D. Carbópolis. 1999. Disponível em: http://www.iq.ufrgs.br/aeq/carbopp.htm.

[8] FREIRE, P. Pedago gia da autonomia: Saberes necessários à prática educativa. São Paulo: Paz e Terra, 1996. 165 p.

[9] FREIRE, F. M. P.; PRADO, M. E. B. B. Projeto pedagógico: pano de fundo para escolha de um software educacional. Disponível em: http://rxmartins.pro.br/teceduc/computador-s ociedade-conhecimento.pdf.
[10] HONEY, Margaret A.; HILTON, Margaret L. National Research Council. Learning Science Through Computer Games and Simulations. Committee on Science Learning: Computer Games, Simulations, and Education, Eds. Board on Science Education, Division of Behavioral and Social Sciences and Education. Washington, DC: The National Academies Press, 2011

[11] JUCÁ, S. A relevância dos softwares educativos na educação profissional. Ciências \& Cognição, Ano 03, v. 08, 2006. Disponível em: www.cienciasecognicao.org.

[12] MORAN, J. M. A educação que desejamos: Novos desafios e como chegar lá. 3. ed. Campinas, SP: Papirus, 2008.

[13] PAIVA, João; GIL, Victor M. S. O Jogo das Coisas 2.0. SPF. Departamento de Física da Universidade de Coimbra / Portugal. Disponível em: www.fis.uc.pt.

[14] SILVA, M. D. Anísio Teixeira à cibercultura: desafios para a formação de professores ontem, hoje e amanhã. Boletim Técnico do Senac, v. 29, n. 3, set./dez. 2003. Disponível em: http://www.senac.br/BTS/293/boltec293c.htm

[15] VALENTE. J. A. (Org.). Coleção Informática para a mudança na educação. O Computador na Sociedade do Conhecimento. p. 80. Disponível em: http://escola2000.net/ eduardo/textos/proinfo/livro02-Jose \%20Valente\%20et\%20al ii.pdf\#page $=71$.

[16] VIEIRA, F. M. S. Avaliação de software educativo: reflexões para uma análise criteriosa. Disponível em: $<$ http://www.edutec.net/Textos/Alia/MISC/edmagali2.htm $>$. Acesso em: 12/03/2009. 